\title{
Relationship between water physico-chemical parameters and growth of Brycinus macrolepidotus (Valenciennes, 1850) in Akomoje water reservoir, Ogun State, Nigeria
}

\author{
F.I. ADEOSUN", A.A. IDOWU, E. O. AJIBOYE and M. T. O. OGHENOCHUKO \\ Department of Aquaculture and Fisheries Management, Federal University of Agriculture, Abeokuta, \\ PMB 2240, Ogun State, Nigeria. \\ *Corresponding author; E-mail: adeosunfi@yahoo.com; Tel: +2348038057564
}

\begin{abstract}
Water pollution is a major topic in many fisheries and aquaculture conferences, seminars and workshops as the performance and survival of any fish species depends on its environment. This study was designed to investigate the relationship between physico-chemical parameters of water and growth of Brycinus macrolepidotus in Akomoje water reservoir, South-West, Nigeria. Water parameters were measured using standard methods. Length and weight of sampled fish were also determined to the nearest $0.1 \mathrm{~cm} / \mathrm{g} \mathrm{using}$ standard equipment. Relationship between water features and length, weight was determined by correlation. All data were analyzed using Statistical Package for Social Sciences software. No significant difference $(\mathrm{p}>0.05)$ was observed in temperature and dissolved oxygen $\left(28.3-28.5^{\circ} \mathrm{C}\right.$ and $\left.7.6-8.2 \mathrm{mg} / \mathrm{l}\right)$ during the study while $\mathrm{pH}$, transparency, nitrate and phosphate varied significantly. Levels of $\mathrm{pH}$ dropped at the peak of the dry months (January) to the onset of the rains (April). Spatial variation in all parameters was not significant ( $p>0.05)$. Length and weight were higher during the wet months $(29.24-31.16 \mathrm{~cm}$ and $625.22-756.18 \mathrm{~g}$ ) than in the dry months (24.45-28.81 cm and 385.71-639.20 g) with maximum recorded in June. Positive relationship was observed between length, weight and temperature. Conclusively, dissolved oxygen and temperature were within optimum range for fish growth during the study. Transparency, $\mathrm{pH}$, nitrate, and phosphate were influenced by the seasons. Correlation was established between growth and water parameters.
\end{abstract}

(C) 2019 International Formulae Group. All rights reserved

Keywords: Dissolved oxygen, physico-chemical parameters, temperature, spatial variation, fish growth

\section{INTRODUCTION}

The quality of any water body plays a vital role in biology and physiology of fish species (Mohammed et al., 2016). Physical, chemical and biological characteristics are some of the basic parameters measured to determine the state of any water body. They include but not limited to all physical (temperature, total suspended solids, depth), chemical (dissolve oxygen, $\mathrm{pH}$, ammonia), and biological (phytoplankton, zooplankton) factors of water which influence growth and survival of the fish in the water and also for other beneficial uses.

Several studies have been carried on the effect of water quality on fish population of various water bodies (Elegbede et al., 2015; Subhendu, 2015). Possible negative effects of environmental factors such as temperature, dissolve oxygen on reproductive behaviour of fish have also been reported. Issa et al. (2005) researched on the effects of some 
environmental factors on the fecundity of Tilapia species (Family Cichlidae) in Kigera Reservoir, New Bussa. Moiseenko (2010) reported on the effect of toxic pollution on fish populations and mechanisms for maintaining population size. Other studies include those of Björnsson et al. (2006) on effects of water quality and stocking density on growth performance of juvenile cod ( Gadus morhua L.), Mannan et al. (2012) on growth and production of cultured fish, Makori et al. (2017) on effect of water physical and chemical parameters on growth of Tilapia (Oreochromis niloticus) in culture facility.

The survival, health and growth of this species like every other fish depend on the water quality variables. Water features affect the biotic factors of any aquatic environment (Olanrewaju et al., 2017). Environmental stress (low dissolved oxygen, high temperature and high ammonia) have been reported to influence the ability of fish to maintain its internal equilibrium during metabolism and reproduction (Avkhimovich, 2013).

There are however few or no report on the effect of water parameters on some aspect of the biology of Brycinus macrolepidotus. Also, the physical and chemical features of any water body give the status, productivity and sustainability of such water body (Bhateria and Jain, 2016). This study was therefore designed to assess the effect of water quality parameters on growth of $B$. macrolepidotus in Akomoje Water Reservoir, Ogun River, Nigeria.

\section{MATERIALS AND METHODS Description of study area}

The study was carried out in lower River Ogun, Akomoje Water Reervoir, Ogun River, Nigeria. The study area is located in Abeokuta North Local Government, and lies between longitude $3^{\circ} 21^{\prime} \mathrm{E}$ to $5^{\circ} 25^{\prime} \mathrm{E}$ and latitude $7^{\circ} 21^{\prime} \mathrm{E}$ to $8^{\circ} 41^{\prime} \mathrm{N}$ North covering a land mass of 1000 hectares of Abeokuta (Ajiboye et al., 2019). River Ogun is a perennial river in Nigeria, which has a coordinate of $3^{\circ} 28^{\prime} \mathrm{E}$ and $8^{\circ} 41^{\prime} \mathrm{N}$ from its source in Oyo State to $3^{\circ} 25^{\prime} \mathrm{E}$ and $6^{\circ} 35^{\prime} \mathrm{N}$ in Lagos State where it enters Lagos Lagoon. Two seasons are distinguishable in Ogun river basin, a dry season from November to March and a wet season between April and October (Oketola et al., 2006). The annual rainfall ranges from $900 \mathrm{~mm}$ in the north of the river to $200 \mathrm{~mm}$ towards the south. Total annual potential evapotranspiration is $1600 \mathrm{~mm}$ and $1900 \mathrm{~mm}$. The land coverage is about 230 $\mathrm{km}^{2}$. The relief is generally low, with the gradient in the north-south direction (Adeosun et al., 2014). The water source is from the Igaran hills at an elevation of about $540 \mathrm{~m}$ above the sea level and flows directly southward over a distance of $480 \mathrm{~km}$ before it discharges into the Lagos Lagoon. The major tributaries of the river are Ofiki and Opeki Rivers (Bhattacharya and Bolaji, 2010). Akomoje reservoir takes its source of water from River Ogun.

\section{Physical and chemical water parameters of Akomoje water reservoir}

Water quality parameters of the reservoir were investigated from three locations which were selected based on proximity to different anthropogenic activities around the reservoir.

Station 1 (Odo Water): It is located downstream of about $1 \mathrm{~km}$ from the bridge across the reservoir. The station is partially flooded with rocks and the substratum is a mixture of rock stones and sand materials, the human activities going around here is solely fishing and bathing.

Station 2 (Oke Dam): This was located $318.52 \mathrm{~m}$ away from station 1 . It is characterized with much sand sediment. The location is close to the Cocoa plantation along the reservoir.

Station 3 (Odo Onigi): This was located at the fishermen landing site. The station is $442.64 \mathrm{~m}$ away from station 2 but along the same course and characterized with muddy sediments of decaying organic materials at the bank of the river. Domestic activities ranging from Farming, fishing, bathing, clothes washing, and much lumbering activities occurs regularly in this station. 
Water physical and chemical parameters were measured in-situ and ex-situ on monthly basis during the study period using standard procedure by America Public Health Association (1989). pH, air temperature $\left({ }^{\circ} \mathrm{C}\right)$, water temperature $\left({ }^{\circ} \mathrm{C}\right)$, conductivity $(\mu \mathrm{s} / \mathrm{cm})$, depth, and transparency were conducted in-situ with the use of HANNA instrument (Model HI 9810). Dissolved oxygen $(\mathrm{mg} / \mathrm{L})$, nitrate $(\mathrm{mg} / \mathrm{L})$, phosphate $(\mathrm{mg} / \mathrm{L})$, and salinity $(\% 0)$ were determined $e x$-situ using standard methods for examination of water (America Public Health Association, 1989).

The samples were taken to the laboratory of the Department of Environmental Management and Toxicology, College of Environmental Resource Management, Federal University of Agriculture, Abeokuta, Nigeria for further analysis.

\section{Collection of fish specimens}

Brycinus macrolepidotus were sampled monthly from the Akomoje water reservoir from November 2015 to July 2016. Sampling was carried-out during the day (8 am GMT $1 \mathrm{pm}$ GMT). 838 fish were procured from fishermen at landing sites. Information from the fishermen showed that the fish were caught using various fishing gears including set traps, gill nets $(22-70 \mathrm{~mm}$ stretched mesh size) and cast nets $(10-12 \mathrm{~mm}$ stretched mesh).Samples collected were put in ice chest and transported to the wet laboratory of the Department of Aquaculture and Fisheries Management, Federal University of Agriculture, Abeokuta, Nigeria and preserved at $4^{\circ} \mathrm{C}$ for subsequent analysis.

\section{Morphological measurements}

Total length (TL) and standard length (SL) were measured using a measuring board. TL was measured from the anterior tip of the fish against a stop at the beginning of the measuring board with its mouth closed to the tip of the caudal fin. SL was taken as the length from the tip of the fish's mouth to the caudal peduncle. All length measurement was to the nearest 0.1 centimeter. The body weight was measured using a digital electronic weighing balance (Adam AFP 4100L). This was read to the nearest 0.1 gram.

\section{Statistical analysis}

Data for water quality parameters were analyzed using descriptive (mean, standard deviation and percentage), and Inferential statistics (analysis of variance, Duncan multiple range test and student $\mathrm{t}$ - test). The relationship between water parameters and length and weight were determined by simple linear relationship using Statistical Package for Social Sciences (SPSS) software Gradpack version 20.0

\section{RESULTS}

Water quality parameters of Akomoje water reservoir, Abeokuta, Ogun State

Monthly variations were observed in all water quality parameters measured during the study as presented in Figures 1-9 in all locations. No significant difference was observed in temperature and dissolved oxygen ( $>0.05)$ during the study. Significant variation $(p<0.05)$ was observed in $\mathrm{pH}$, transparency, nitrate and phosphate. Levels of $\mathrm{pH}$ were observed to drop at the peak of the dry months (January) to the onset of the rains (April) as shown in Table 1. Temperature ranged from 28.1 - 29.2 in the various stations, DO and $\mathrm{pH}$ ranges were $8.0-9-3$ and $6.1-6.9$ respectively. No significant difference $(p>0.05)$ was recorded in all the measured parameters in all study locations as revealed in Table 2.

\section{Length and weight of Brycinus macrolepidotus from the study area}

Table 3 shows the mean length and weight of the fish species. Higher growth in length and weight was recorded in the wet months than in the dry months with maximum length and weight recorded in the month of June for males, females and combined sexes. Mean total length for male species ranged from $24.29-31.38 \mathrm{~cm}$ while for females range was from $24.55-30.53 \mathrm{~cm}$. Body weight of the fish specimen for males ranged 
from $384.79-786.2 \mathrm{~g}$ and for females, range was from $387.09-727.37 \mathrm{~g}$.

\section{Correlation between Brycinus} macrolepidotus growth (weight and length) and physico-chemical parameters

Strong positive relationship was observed between water temperature, electrical conductivity, salinity and transparency, and fish weight and length in the month of June. Dissolved oxygen, nitrate and phosphate showed negative correlation with fish weight and length in virtually all the months of the study as shown in Table 4.

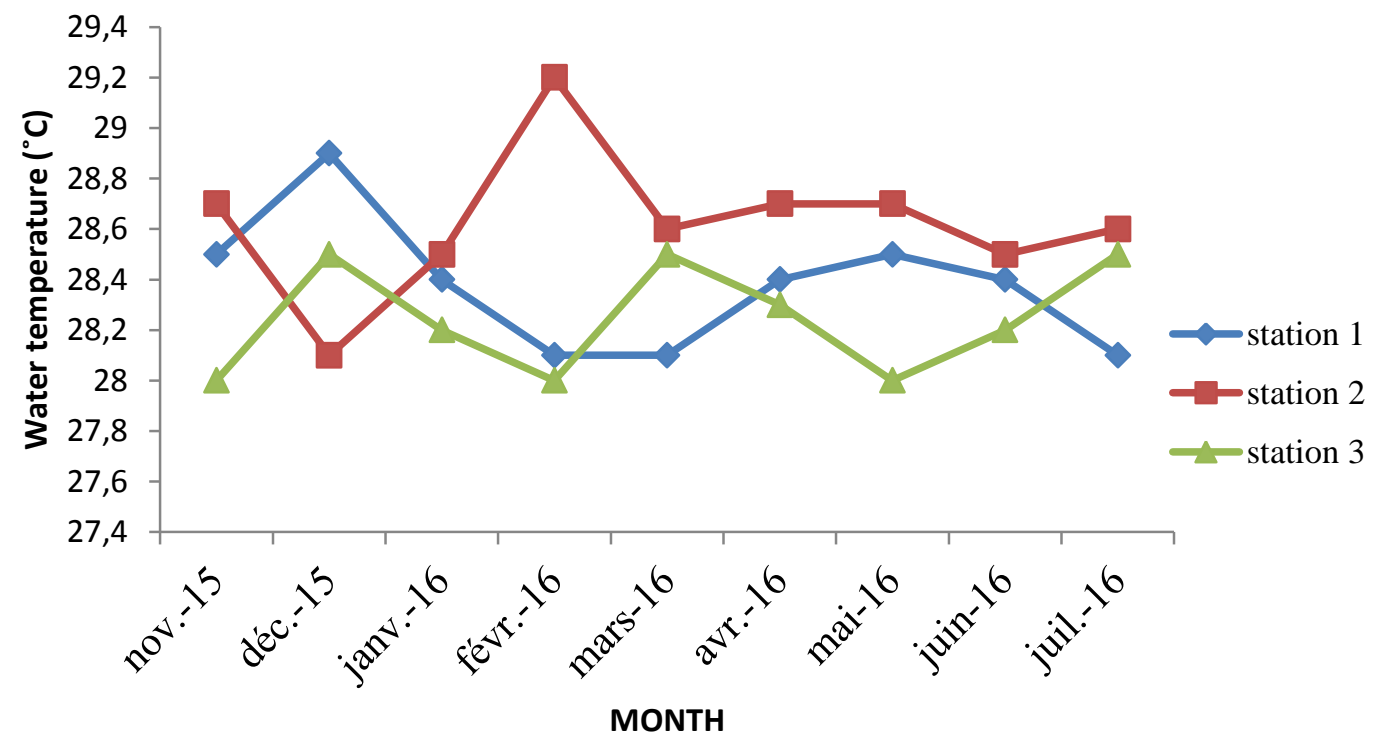

Figure 1. Monthly variation of water temperature in Akomoje water reservoir, Ogun State

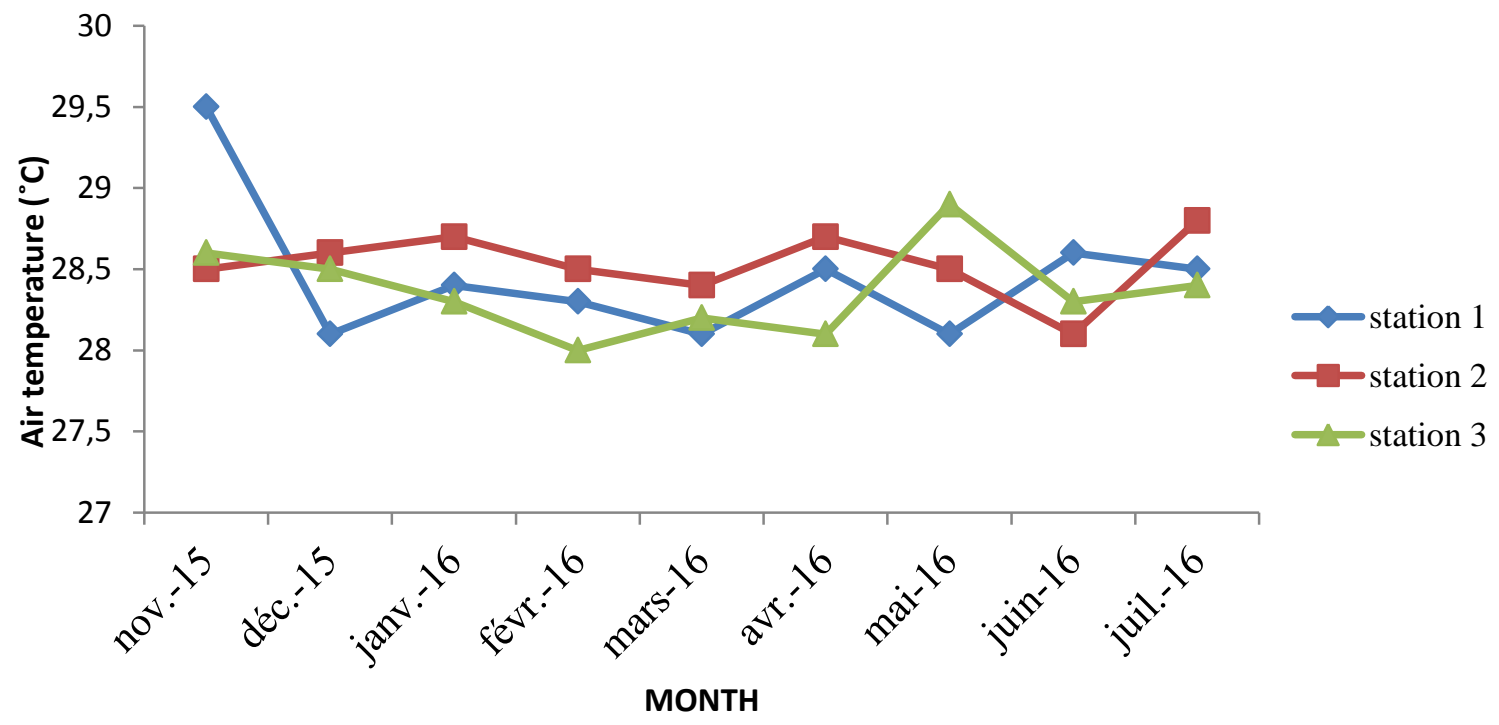

Figure 2: Monthly variation of air temperature in Akomoje water reservoir, Ogun State. 


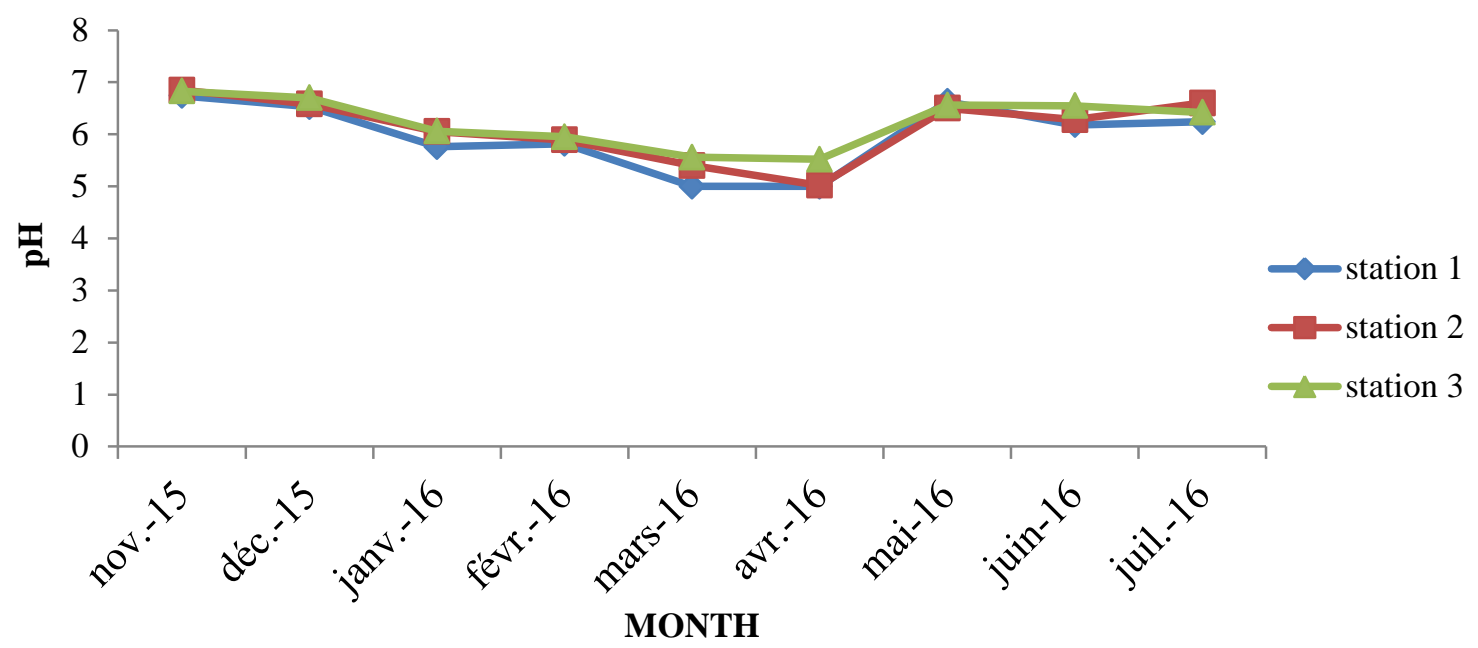

Figure 3: Monthly variation of the $\mathrm{pH}$ in Akomoje water reservoir, Ogun State.

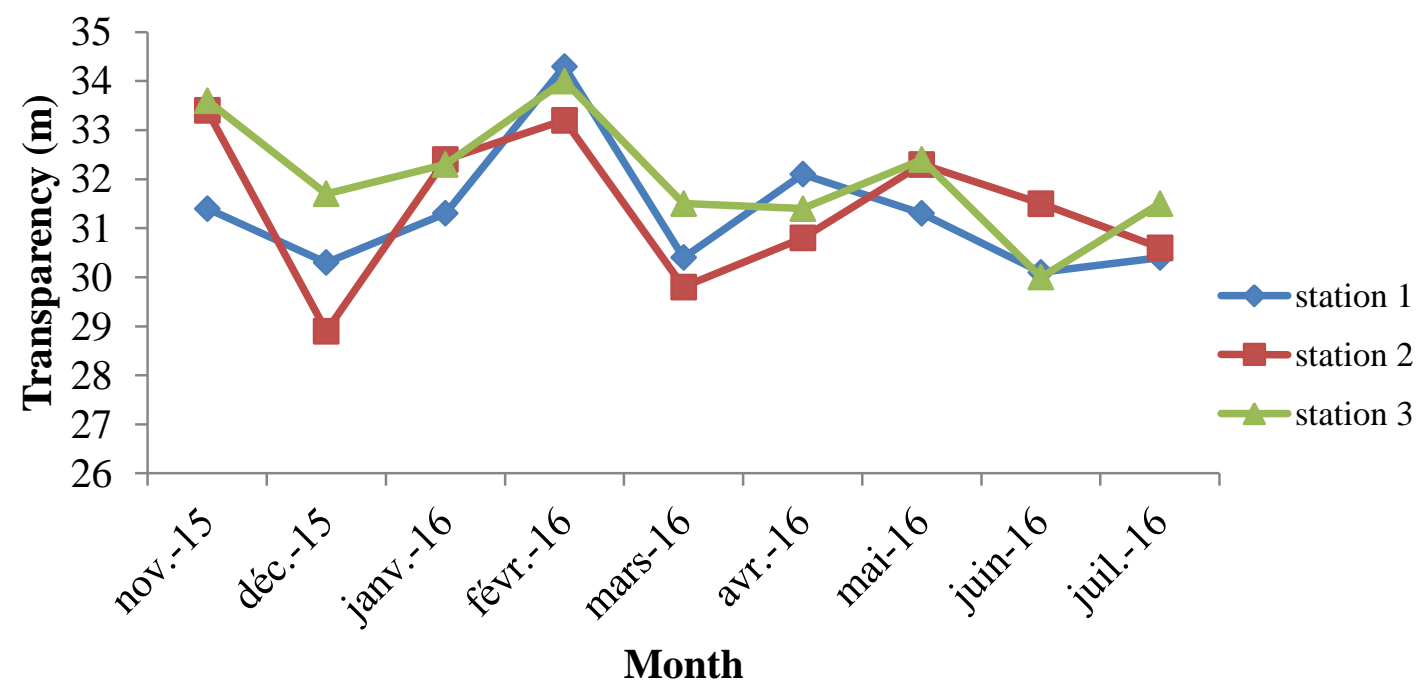

Figure 4: Monthly variation of transparency value in Akomoje water reservoir, Ogun State.

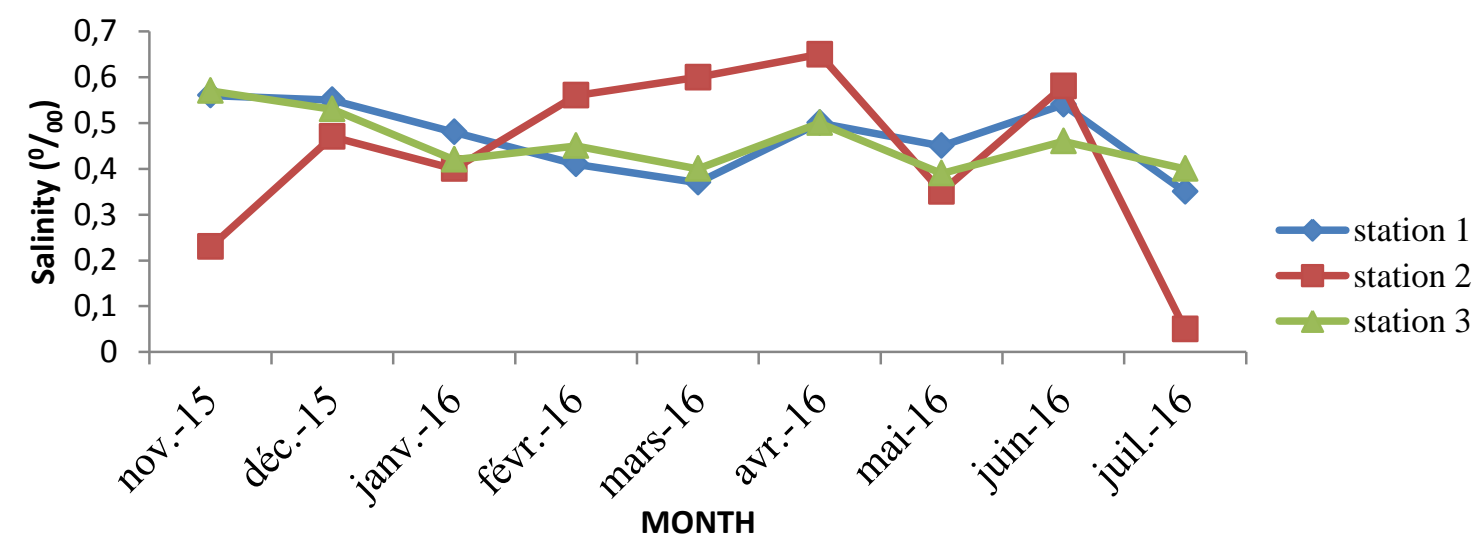

Figure 5: Monthly variation in the salinity value of Akomoje water reservoir, Ogun State. 


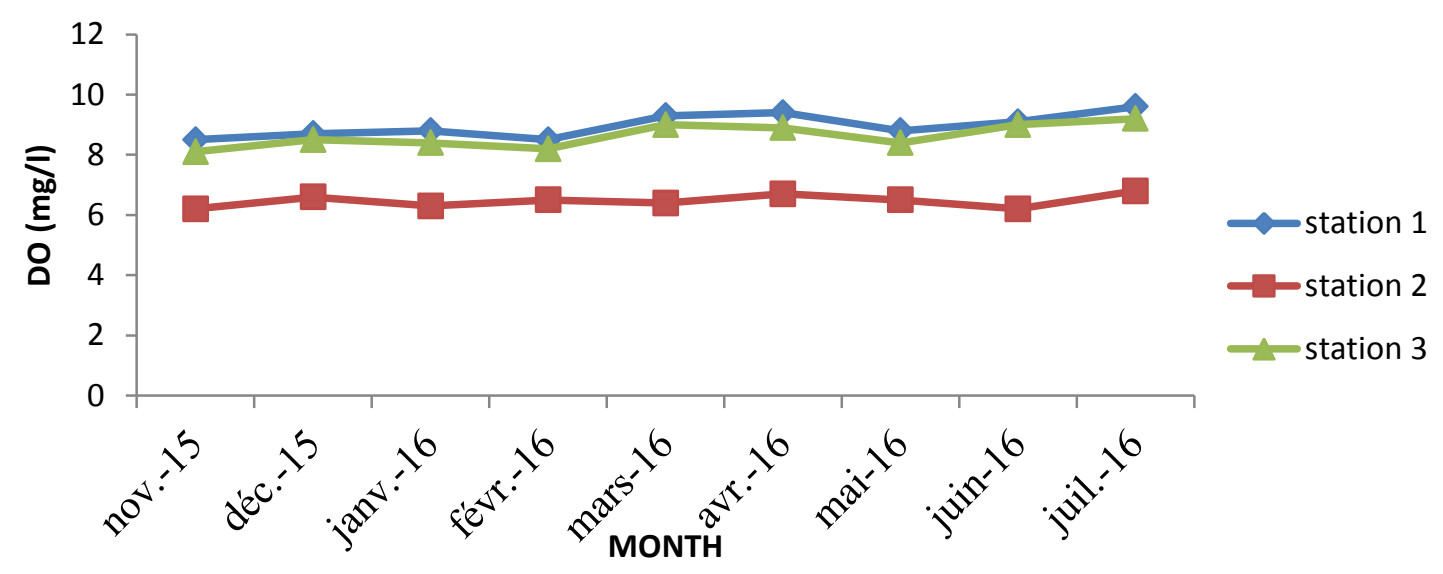

Figure 6: Monthly variation in dissolved oxygen level of Akomoje water reservoir, Ogun State.

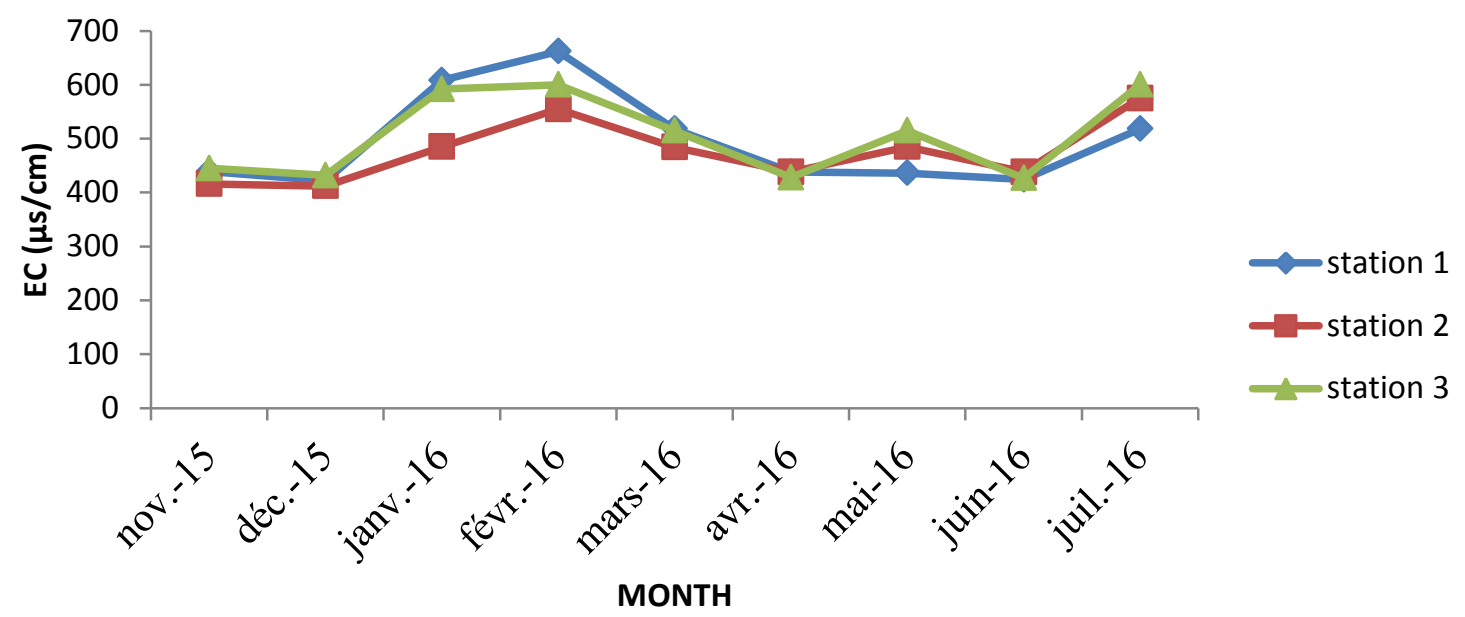

Figure 7: Monthly variation in electrical conductivity of Akomoje water reservoir, Ogun State.

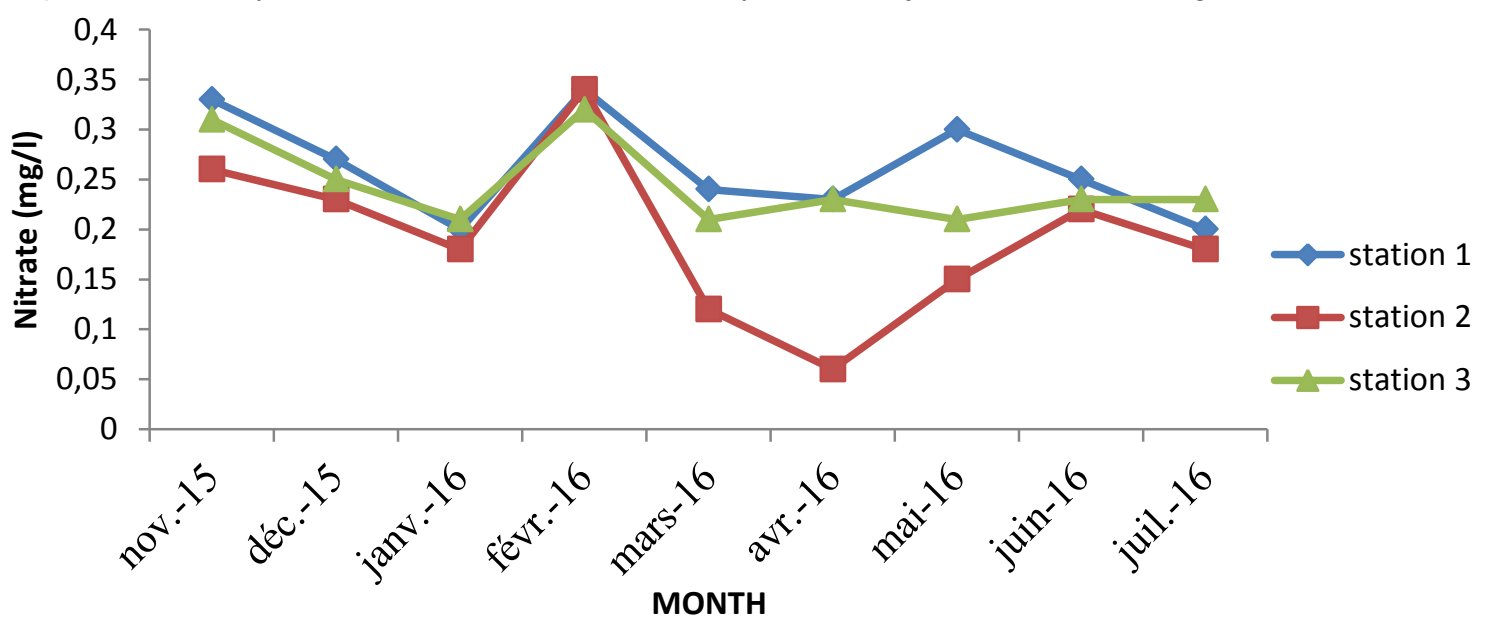

Figure 8: Monthly variation in the nitrate level of Akomoje water reservoir, Ogun State. 


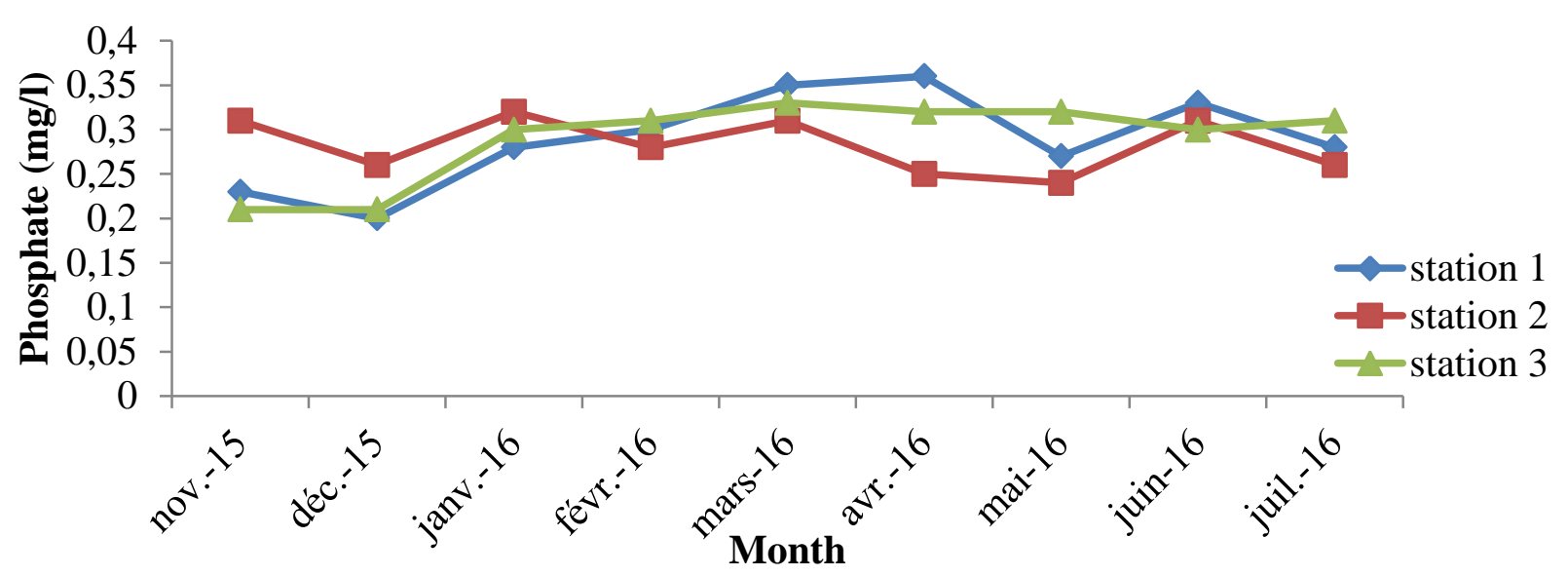

Figure 9: Monthly variation in the phosphate level of Akomoje water reservoir, Ogun State.

Table 1: Temporal water quality parameters of Akomoje reservoir in lower Ogun River.

\begin{tabular}{|c|c|c|c|c|c|c|c|c|c|}
\hline Month & NOV & $\mathrm{DEC}$ & JAN & FEB & MAR & APRIL & MAY & JUNE & JULY \\
\hline WT & $28.4 \pm 0.21^{\mathrm{a}}$ & $28.5 \pm 0.23^{\mathrm{a}}$ & $28.37 \pm 88^{\mathrm{a}}$ & $28.43 \pm 0.38^{\mathrm{a}}$ & $28.40 \pm 0.15^{\mathrm{a}}$ & $28.53 \pm 0.88^{\mathrm{a}}$ & $28.5 \pm 0.11^{\mathrm{a}}$ & $28.30 \pm 0.15^{\mathrm{a}}$ & $28.40 \pm 0.15^{\mathrm{a}}$ \\
\hline AT & $28.87 \pm 0.32^{\mathrm{a}}$ & $28.40 \pm 0.12^{\mathrm{ab}}$ & $28.47 \pm 0.12^{\mathrm{ab}}$ & $28.27 \pm 0.15^{\mathrm{ab}}$ & $28.23 \pm 0.88^{\mathrm{b}}$ & $28.43 \pm 0.18^{\mathrm{ab}}$ & $28.40 \pm 0.23^{\mathrm{ab}}$ & $28.33 \pm 0.11^{\mathrm{ab}}$ & $28.57 \pm 0.12^{\mathrm{ab}}$ \\
\hline $\mathrm{pH}$ & $6.81 \pm 0.03^{\mathrm{a}}$ & $6.60 \pm 0.15^{\mathrm{ab}}$ & $5.96 \pm 0.09^{\mathrm{ab}}$ & $5.89 \pm 0.04^{c}$ & $5.32 \pm 0.17^{\mathrm{d}}$ & $5.18 \pm 0.17^{\mathrm{d}}$ & $6.50 \pm 0.10^{\mathrm{ab}}$ & $6.34 \pm 0.11^{b}$ & $6.42 \pm 0.10^{\mathrm{ab}}$ \\
\hline Trans & $32.80 \pm 0.70^{\mathrm{a}}$ & $30.30 \pm 0.81^{\mathrm{b}}$ & $32.67 \pm 0.88^{\mathrm{ab}}$ & $32.53 \pm 1.09^{\mathrm{ab}}$ & $31.13 \pm 0.69^{\mathrm{ab}}$ & $31.17 \pm 0.19^{\mathrm{ab}}$ & $31.60 \pm 0.75^{\mathrm{ab}}$ & $30.63 \pm 0.45^{\mathrm{ab}}$ & $30.87 \pm 0.32^{\mathrm{ab}}$ \\
\hline Sal & $0.05 \pm 0.01^{\mathrm{ab}}$ & $0.05 \pm 0.02^{\mathrm{a}}$ & $0.04 \pm 0.04^{\mathrm{ab}}$ & $0.04 \pm 0.02^{\mathrm{ab}}$ & $0.04 \pm 0.03^{\mathrm{ab}}$ & $0.05 \pm 0.04^{\mathrm{a}}$ & $0.04 \pm 0.03^{\mathrm{ab}}$ & $0.05 \pm 0.04^{\mathrm{ab}}$ & $0.04 \pm 0.01^{\mathrm{b}}$ \\
\hline $\mathrm{DO}$ & $7.60 \pm 0.70^{\mathrm{a}}$ & $7.93 \pm 0.67^{\mathrm{a}}$ & $7.83 \pm 0.78^{\mathrm{a}}$ & $7.73 \pm 0.62^{\mathrm{a}}$ & $8.23 \pm 0.92^{\mathrm{a}}$ & $8.13 \pm 0.72^{\mathrm{a}}$ & $8.00 \pm 0.78^{\mathrm{a}}$ & $8.27 \pm 1.05^{\mathrm{a}}$ & $8.33 \pm 0.77^{\mathrm{a}}$ \\
\hline $\mathrm{EC}$ & $433.33 \pm 8.84^{\mathrm{c}}$ & $422.00 \pm 5.77^{\mathrm{c}}$ & $561.66 \pm 38.61^{\mathrm{ab}}$ & $605.67 \pm 31.02^{\mathrm{a}}$ & $505.67 \pm 10.87^{\mathrm{bc}}$ & $433.67 \pm 3.38^{\mathrm{c}}$ & $474.67 \pm 26.77^{\mathrm{bc}}$ & $506.67 \pm 43.09^{\mathrm{bc}}$ & $548.33 \pm 55.23^{\mathrm{ab}}$ \\
\hline Nit & $0.30 \pm 0.02^{\mathrm{bc}}$ & $0.25 \pm 0.11^{\mathrm{c}}$ & $0.20 \pm 0.01^{\mathrm{abc}}$ & $0.34 \pm 0.00^{\mathrm{ab}}$ & $0.23 \pm 0.58^{\mathrm{a}}$ & $0.25 \pm 0.27^{\mathrm{bc}}$ & $0.19 \pm 0.02^{c}$ & $0.20 \pm 0.02^{c}$ & $0.21 \pm 0.02^{\mathrm{c}}$ \\
\hline Pho & $0.25 \pm 0.03^{b c}$ & $0.25 \pm 0.02^{\mathrm{c}}$ & $0.31 \pm 0.01^{\mathrm{abc}}$ & $0.31 \pm 0.02^{\mathrm{a}}$ & $0.33 \pm 0.02^{\mathrm{a}}$ & $0.28 \pm 0.02^{\mathrm{abc}}$ & $0.27 \pm 0.07^{\mathrm{a}}$ & $0.27 \pm 0.01^{\mathrm{abc}}$ & $0.28 \pm 0.02^{\mathrm{abc}}$ \\
\hline
\end{tabular}

Mean values with the same superscript along the rows were not significantly $(\mathrm{p}>0.05)$ different.

WT - Water temperature $\left({ }^{\circ} \mathrm{C}\right)$, AT- Air temperature $\left({ }^{\circ} \mathrm{C}\right)$, pH- Hydrogen ion concentration, Trans - Transparency $(\mathrm{cm})$, Sal - Salinity $(\% 00)$, DO - Dissolved oxygen (mg/l), EC - Electrical conductivity $(\mu \mathrm{s} / \mathrm{cm})$, Nit - Nitrate (mg/l), Pho - Phosphate (mg/l). NOV-November, DEC-December, JAN- January, FEB- February, MAR- March. 
Table 2: Spatial water quality parameters of Akomoje water reservoir lower Ogun River.

\begin{tabular}{lcccccc}
\hline \multirow{2}{*}{ Parameter } & \multicolumn{2}{c}{ STATION 1 } & \multicolumn{2}{c}{ STATION 2 } & \multicolumn{2}{c}{ STATION 3 } \\
& Range & Mean \pm SE & Range & Mean \pm SE & Range & Mean \pm SE \\
\hline Air Temperature $\left({ }^{\circ} \mathrm{C}\right)$ & $28.1-29.50$ & $28.6 \pm 0.17^{\mathrm{a}}$ & $28.1-28.70$ & $28.5 \pm 0.12^{\mathrm{a}}$ & $28.1-28.90$ & $28.4 \pm 0.11^{\mathrm{a}}$ \\
\hline Water Temperature $\left({ }^{\circ} \mathrm{C}\right)$ & $28.1-28.50$ & $28.4 \pm 0.12^{\mathrm{a}}$ & $28.1-29.20$ & $28.6 \pm 0.13^{\mathrm{a}}$ & $28.0-28.50$ & $28.3 \pm 0.84^{\mathrm{a}}$ \\
$\mathrm{P}^{\mathrm{H}}$ & $6.2-6.90$ & $6.5 \pm 0.10^{\mathrm{a}}$ & $6.1-6.70$ & $6.4 \pm 0.07^{\mathrm{a}}$ & $6.2-6.80$ & $6.5 \pm 0.09^{\mathrm{a}}$ \\
Transparency $(\mathrm{m})$ & $30-34.30$ & $31.5 \pm 0.58^{\mathrm{a}}$ & $29.8-33.20$ & $30.9 \pm 0.55^{\mathrm{a}}$ & $30.5-34.00$ & $31.8 \pm 0.44^{\mathrm{a}}$ \\
Salinity $(\% \mathbf{0 0})$ & $0.03-0.05$ & $0.04 \pm 0.03^{\mathrm{a}}$ & $0.01-0.06$ & $0.04 \pm 0.01^{\mathrm{a}}$ & $0.02-0.05$ & $0.02 \pm 0.01^{\mathrm{a}}$ \\
Dissolve oxygen $(\mathrm{mg} / \mathrm{l})$ & $8.6-9.60$ & $9.0 \pm 0.16^{\mathrm{a}}$ & $8.0-8.98$ & $8.8 \pm 0.33^{\mathrm{a}}$ & $8.0-9.30$ & $8.83 \pm 0.18^{\mathrm{a}}$ \\
Conductivity $(\mu \mathrm{S} / \mathrm{cm})$ & $422-662$ & $514.5 \pm 37.5^{\mathrm{a}}$ & $412-555$ & $465 \pm 20.3^{\mathrm{a}}$ & $428-600$ & $502.0 \pm 29.6^{\mathrm{a}}$ \\
Nitrate $(\mathrm{mg} / \mathrm{l})$ & $0.18-0.31$ & $0.24 \pm 0.02^{\mathrm{a}}$ & $0.05-0.30$ & $0.18 \pm 0.03^{\mathrm{a}}$ & $0.20-0.31$ & $0.24 \pm 0.02^{\mathrm{a}}$ \\
Phosphate $(\mathrm{mg} / \mathrm{l})$ & $0.19-0.33$ & $0.26 \pm 0.02^{\mathrm{a}}$ & $0.24-0.35$ & $0.29 \pm 0.01^{\mathrm{a}}$ & $0.2-0.31$ & $0.28 \pm 0.02^{\mathrm{a}}$ \\
\hline
\end{tabular}

Mean values with the same superscript along the rows were not significantly ( $>>0.05)$ different.

Table 3: Mean total length and weight of Brycinus macrolepidotus from Akomoje water reservoir.

\begin{tabular}{lcccc}
\hline MONTH & PARAMETER & MALE & FEMALE & COMBINED \\
\hline NOVEMBER & $\mathrm{N}$ & 75 & 37 & 112 \\
& mean L $\pm \mathrm{se}(\mathrm{cm})$ & $26.96 \pm 5.96$ & $24.55 \pm 5.99$ & $26.16 \pm 6.05$ \\
DECEMBER & mean Wt $\pm \mathrm{se}(\mathrm{g})$ & $524.61 \pm 279.55$ & $417.65 \pm 251.09$ & $489.28 \pm 274.04$ \\
& $\mathrm{~N}$ & 53 & 35 & 88 \\
& mean L $\pm \mathrm{se}(\mathrm{cm})$ & $24.29 \pm 5.47$ & $24.69 \pm 6.21$ & $24.45 \pm 5.74$ \\
JANUARY & mean Wt $\pm \mathrm{se}(\mathrm{g})$ & $384.79 \pm 231.42$ & $387.09 \pm 266.28$ & $385.71 \pm 244.38$ \\
& $\mathrm{~N}$ & 43 & 26 & 69 \\
FEBRUARY & mean L $\pm \mathrm{se}(\mathrm{cm})$ & $30.16 \pm 6.08$ & $26.58 \pm 6.86$ & $28.81 \pm 6.57$ \\
& mean Wt $\pm \mathrm{se}(\mathrm{g})$ & $712.88 \pm 346.85$ & $517.35 \pm 345.99$ & $639.20 \pm 356.97$ \\
& $\mathrm{~N}$ & 85 & 27 & 112 \\
MARCH & mean L $\pm \mathrm{se}(\mathrm{cm})$ & $25.73 \pm 6.07$ & $25.92 \pm 6.52$ & $25.72 \pm 6.21$ \\
& mean Wt $\pm \mathrm{se}(\mathrm{g})$ & $440.87 \pm 320.49$ & $460.87 \pm 350.50$ & $445.67 \pm 330.07$ \\
& $\mathrm{~N}$ & 80 & 27 & 107 \\
APRIL & mean L $\pm \mathrm{se}(\mathrm{cm})$ & $28.64 \pm 4.78$ & $29.80 \pm 3.06$ & $28.71 \pm 4.59$ \\
& mean Wt $\pm \mathrm{se}(\mathrm{g})$ & $649.30 \pm 261.70$ & $683.22 \pm 191.40$ & $638.97 \pm 250.00$ \\
MAY & $\mathrm{N}$ & 51 & 30 & 81 \\
& mean L $\pm \mathrm{se}(\mathrm{cm})$ & $29.28 \pm 4.27$ & $29.15 \pm 4.48$ & $29.24 \pm 4.32$ \\
& mean Wt $\pm \mathrm{se}(\mathrm{g})$ & $668.90 \pm 215.90$ & $660.13 \pm 228.34$ & $665.65 \pm 219.21$ \\
& mean L $\pm \mathrm{se}(\mathrm{cm})$ & $29.62 \pm 4.15$ & $30.81 \pm 3.65$ & 86 \\
& mean Wt $\pm \mathrm{se}(\mathrm{g})$ & $614.18 \pm 202.10$ & $727.37 \pm 350.4$ & $625.22 \pm 286.8$
\end{tabular}


JUNE $\mathrm{N}$

64

30

94

mean $\mathrm{L} \pm \operatorname{se}(\mathrm{cm})$

$31.38 \pm 4.28$

$30.46 \pm 3.21$

$786.22 \pm 264.94$

63

$724.61 \pm 228.01$

$\mathrm{N}$

26

$31.16 \pm 3.88$

$756.18 \pm 218.62$

89

mean $\mathrm{L} \pm \mathrm{se}(\mathrm{cm})$

$30.35 \pm 0.68$

$30.53 \pm 0.43$

$30.28 \pm 0.42$

mean $\mathrm{Wt} \pm \mathrm{se}(\mathrm{g})$

$670.96 \pm 320.15$

$665.13 \pm 270.25$

$652.61 \pm 284.11$

Table 4: Correlation of fish length, weight and physical and chemical water quality parameters.

\begin{tabular}{|c|c|c|c|c|c|c|c|c|c|c|}
\hline \multirow[t]{2}{*}{ Months } & \multirow{2}{*}{$\begin{array}{l}\text { Growth } \\
\text { Parameters }\end{array}$} & \multicolumn{9}{|c|}{ Water parameters } \\
\hline & & $\begin{array}{l}\text { Air } \\
\text { temp }\end{array}$ & Temp & DO & pH & EC & Salinity & Trans & Nitr & Phosphate \\
\hline \multirow[t]{2}{*}{ Nov } & TL & -0.939 & 0.197 & -0.903 & $0.963^{*}$ & -0.695 & -0.807 & $0.866^{*}$ & -0.947 & $0.699 *$ \\
\hline & WT & -0.701 & $0.599 *$ & -1.00 & $0.756^{*}$ & -0.936 & -0.982 & $0.567 *$ & -0.993 & $0.939 *$ \\
\hline \multirow[t]{2}{*}{ Dec } & TL & -0.990 & $0.982^{*}$ & $0.809 *$ & -0.462 & 0.327 & 0.891 & 0.327 & $0.982 *$ & -0.849 \\
\hline & WT & -0.989 & $0.982^{*}$ & $0.990^{*}$ & 0.283 & 0.892 & 0.956 & $0.892^{*}$ & $0.838^{*}$ & -0.978 \\
\hline \multirow[t]{2}{*}{ Jan } & TL & 0.208 & -0.259 & -0.565 & $0.999 *$ & -0.541 & -0.950 & $0.988 *$ & -0.118 & $0.828^{*}$ \\
\hline & WT & -0.797 & -0.984 & $0.506^{*}$ & 0.386 & 0.531 & -0.125 & 0.281 & $0.849^{*}$ & -0.156 \\
\hline \multirow[t]{2}{*}{ Feb } & TL & -0.596 & -0.075 & -0.139 & $0.999 *$ & -0.577 & 0.258 & -0.264 & -0.866 & 0.327 \\
\hline & WT & -0.585 & -0.061 & -0.152 & $0.999 *$ & -0.588 & 0.2701 & -0.277 & -0.859 & 0.314 \\
\hline \multirow[t]{2}{*}{ March } & TL & 0.9812 & $0.945^{*}$ & -0.909 & $0.693 *$ & -0.903 & 0.919 & -0.348 & -0.961 & -1.000 \\
\hline & WT & 0.971 & $0.960^{*}$ & -0.887 & $0.729 *$ & -0.881 & 0.899 & -0.301 & -0.946 & -0.999 \\
\hline \multirow[t]{2}{*}{ April } & TL & -0.189 & 0.277 & -0.643 & $0.529 *$ & -0.500 & 0.500 & -0.887 & -0.500 & -0.778 \\
\hline & WT & 0.327 & 0.721 & $0.939 *$ & -0.034 & 0.000 & -0.866 & $0.999 *$ & $0.866^{*}$ & $0.988^{*}$ \\
\hline \multirow[t]{2}{*}{ May } & TL & 0.189 & $0.577^{*}$ & -0.999 & -0.929 & 0.322 & -0.901 & $0.590 *$ & -0.901 & -0.654 \\
\hline & WT & 0.019 & $0.707 *$ & -0.989 & -0.854 & 0.157 & -0.815 & 0.445 & -0.815 & -0.773 \\
\hline \multirow[t]{2}{*}{ June } & TL & -0.576 & $0.923^{*}$ & -0.939 & -0.546 & 0.866 & 0.923 & $0.967^{*}$ & -0.513 & 0.128 \\
\hline & WT & -0.429 & $0.975^{*}$ & -0.868 & -0.679 & 0.769 & 0.975 & $0.909^{*}$ & -0.360 & 0.294 \\
\hline \multirow[t]{2}{*}{ July } & TL & -0.500 & -0.999 & $0.783^{*}$ & -0.961 & -0.855 & 0.592 & -0.437 & 0.127 & 0.127 \\
\hline & WT & -0.157 & $0.809^{*}$ & -0.216 & $0.572 *$ & 0.991 & 0.047 & $0.906^{*}$ & $0.525^{*}$ & $0.526^{*}$ \\
\hline
\end{tabular}

Key: NOV-November, DEC-December, JAN- January, FEB- February. Temp- temperature, Trans - Transparency DO Dissolved oxygen, EC - Electrical conductivity, Nit - Nitrate, TL - total length, WT - body weight 


\section{DISCUSSION}

The physical and chemical features of Akomoje water reservoir, Ogun State, Nigeria showed spatial and temporal variations during the study, which might be associated with patterns of water use and rainfall (Ayoade et al., 2006). These interactions were however minimal especially with the levels of water temperature, and dissolved oxygen at the different study locations and in all months of the study. The result obtained for all the parameters at the three stations indicated a direct proportionate relationship in the values.

Temperature range reported during the study and in all the locations was within the range reported for the species (Paugy and Schaefer, 2007) for optimum growth and reproduction, indicating no spatial or temporal variations in the study area. This might be due to constant water flows or currents in the reservoir channel that helped to distribute the heat energy absorbed at the water surface more or less uniformly in the river. Water temperature is one of the most important physical parameters of aquatic systems (Kamal et al., 2007). It is the most important regulators of life processes in aquatic ecosystems (Federal Office for the Environment, 2011) as it affects growth, nutrition, reproduction and metabolism. Temperature is clearly the dominant feature and is correlated with winter but the growth rate coincides with a drop in temperature. Temperature also influences the rate of photosynthesis by algae and aquatic plants. As water temperature rises, the rate of photosynthesis increases thereby providing adequate amounts of nutrients (Boulton, 2012). The temperature variation recorded during the study was optimum for normal growth and survival of aquatic organisms which ranged between $28.0-29.5{ }^{\circ} \mathrm{C}$ for tropical fish (Eniade and Bello-Olusoji, 2011). This result was similar to that of Adeosun et al. (2014) who reported a range of $27.5^{\circ} \mathrm{C}$ $30.5{ }^{\circ} \mathrm{C}$ for lower Ogun River, Akomoje, Ogun State, Nigeria.

The $\mathrm{pH}$ of the study area did not vary significantly among the stations and ranged between 6.10 and 6.90 indicating that the reservoir water was nearly neutral which agreed with earlier studies in savannah rivers (Bouillon et al., 2014). Significant variation observed between the peak of the dry months and the wet months gave an indication of increased levels of hydrogen ions in the study area during the dry months. No relationship was however reported for $\mathrm{pH}$ and temperature in this study as opposed to the documented fact that increased in temperature result to decrease in $\mathrm{pH}$ levels (Wang and Jackson, 2016). $\mathrm{pH}$ less than 5.5 was reported to limit the growth and reproduction of fish (Crane, 2006). He however stated that $\mathrm{pH}$ range ideal for freshwater fish should range from 6.5 7.0, though other literatures documented $\mathrm{pH}$ range of 6.5 to 9.0 as recommended for the survival and reproduction of fish (Abu Hena et al., 2011).

Water transparency depends on the amount of particles in the water. These particles can be algae or sediment from erosion. Increase in particles would lead to low water transparency and vice versa. Temporal variation in transparency with low values in the dry months was recorded during the study. The higher dry season secchi-disc transparency mean value compared with that of the wet season could be due to absence of floodwater, surface run-offs and settling effect of suspended materials that followed the cessation of rainfall. Zhong et al. (2017) also observed that onset of rain decreased the secchi-disc visibility in a typical Karst River. Wetzel (2001) reported that photosynthesis activities increased with increase in transparency. The lower transparency of the reservoir water in April-July was primarily due to the runoffs of sediment laden rain water into the reservoir, and also due to the increase in phytoplankton density in the reservoir. This finding also corroborated that reported by Ayoola and Ajani (2009) who reported more turbid water during the wet months.

The dissolved oxygen value for the reservoir was high during the study months which could be due to chemical and biological oxidation process at the locations. Temporal and spatial variations in dissolved oxygen 
were observed during the study. Monthly DO levels were highest in the wet months than in the dry months. This could be attributed to decrease water temperature during the wet months. This was however not the case with the study of Munoz et al. (2015) who reported higher DO concentration in the dry months than during the wet months. The dissimilarity between these findings could be due to the different climatic conditions prevalent in the study locations. Dissolved oxygen levels in the study area were found to be higher in the Station 1, followed by Station 3 in the reservoir. This finding probably indicated that vegetation cover on the water surface reduces dissolved oxygen levels possibly through reducing surface aeration and wave actions that could facilitate rapid absorption of atmospheric air into the water and this agreed with the study of Welcomme (1985) who documented that vegetation cover on a water surface reduced dissolved oxygen. The dissolved oxygen levels observed in all the stations could also be attributed to differences in the water currents; water depths and vegetation cover characteristics of the various stations.

The total length ranges recorded for members of the Brycinus family in White Volta River was 6.5- $7.5 \mathrm{~cm}$ (Abobi and Ekau, 2013; Olalekan et al., 2015), River Jamieson 9.6-26.1 cm (Ikomi and Sikoki, 2003), 12-23 $\mathrm{cm}$ in Asa reservoir (Saliu, 2002). However, larger sizes of $B$. macrolepidotus were obtained during this study when compared with that of other Brycinus species from other water bodies. Increased in mean length and weight of the species was recorded in the onset of the rains to the peak of the wet months. This could be attributed to increase in fish food influx into the study location during the wet months (Olapade and Tarawallie, 2014). Abundant feeding during the high water and fasting during low water is, perhaps, not as simple as it appears but was in agreement with the findings of Willoughby and Tweddle (1978).

Strong positive correlation between temperature and fish growth in some of the months during the study support earlier studies on the effect of temperature on growth. According to Makori et al. (2017), temperature showed strong positive correlation with mean length and weight of Oreochromis niloticus in earthen ponds. This is so because increase in water temperature gives rise to a corresponding increase in the rate of photosynthesis thereby resulting in increase of adequate amounts of nutrients and food in the water body (Boulton, 2012). This finding also agreed with the findings of Kausar and Salim (2006). However, strong negative correlation between temperature and fish growth obtained especially in January and February did not follow the documented relationship between growth and temperature. This finding also corroborated the findings of Suja et al. (2009). Reasons for this negative correlation though not clear but could be due to other factors affecting fish growth such as reproduction and population density. Negative correlation was obtained in both the dry and wet months of the study between dissolved oxygen and mean length and weight of Brycinus macrolepidotus. This did not corroborate with past research on the correlation between dissolved oxygen levels and mean fish weight and length reported by Makori et al. (2017) for O. niloticus. According to Mallya (2007), increased in DO levels led to a corresponding increase in specific growth rate (SGR), feed conversion rate (FCR) and fish growth. Correlation between $\mathrm{pH}$ and growth was positive in the dry months indicating that increased $\mathrm{pH}$ would lead to corresponding increase in growth but this was not the case in the peak of the wet months implying that increased in $\mathrm{pH}$ could lead to decrease growth of the species. Reasons were not clear as the study of Sagar et al. (2012) showed that low pH would make fish to lose their appetite and thus growth capacity. Relationship between transparency and growth in both dry (November-January) and wet months (April-July) affirmed that the higher the transparency, the higher the process of primary production resulting to availability of food in the water body. During the wet season, transparency of the water was observed to be low due to turbulence and high 
turbidity corresponding to low primary productivity. This is so because turbidity leads to reduced light penetration, which in turn resulted to reduced photosynthesis and primary productivity (Ufodike et al., 2001). However growth of the species was higher in these wet months than in the dry months.

\section{Conclusion}

In conclusion, dissolved oxygen and temperature in Akomoje reservoir were within optimum range for fish growth and survival during the study. Transparency, $\mathrm{pH}$, nitrate, and phosphate were influenced by the season. High growth was observed in the wet months compared to the dry months. Correlation was established between growth and water parameters. Findings from this study could be used for the management of this fish species and in taking management decision for its fisheries sustenance.

\section{COMPETING INTERESTS}

The authors declare that they have no competing interests.

\section{AUTHORS' CONTRIBUTIONS}

AEO and AFI designed the study and sample collection and data analysis were done by AEO. OMTO, IAA and AEO participated in results, statistics and interpretation. OMTO wrote the draft manuscript, while OMTO, IAA and AFI edited it.

\section{ACKNOWLEDGEMENTS}

The authors are grateful to the laboratory technologist and laboratory attendant at the Department of Aquaculture and Fisheries Management, Federal University of Agriculture, Abeokuta, Nigeria.

\section{REFERENCES}

Abobi SM, Ekau W. 2013. Length-weight relationships and condition factors of Alestes baremoze,Brycinus nurse and Schilbe intermedius from the lower reaches of White Volta River (Yapei), Ghana. Ethiopian J. Environ. Stud. Management, 49: 447-538.
Abu Hena MK, Idris MH, Wong SK, Kibria MM. 2011. Growth and Survival of Indian Salmon Eleutheronema tetradactylum (Shaw, 1804) in Brackish Water Pond. J. Fisheries Aqua. Sci., 6: 479-484. DOI: 10.3923/jfas.2011.479.484.

Adeosun FI, Akin-Obasola BJ, Oyekanmi FB, Kayode JO. 2014. Physical and Chemical Parameters of Lower Ogun River Akomoje, Ogun State, Nigeria. $J$. Fisheries Aquacul., 5: 88-101.

Ayoola SO, Ajani EK. 2009. Seasonal variation in fish distribution and physico-chemical parameters of wetland areas in Oyo State, Nigeria. Int. J. Biol. Chem. Sci., 3(1): 107-116.

Ajiboye EO, Adeosun FI, Oghenochuko OMT. 2019. Assessment of fecundity of Brycinus macrolepidotus in Akomoje water reservoir, Abeokuta, South West, Nigeria. Egyptian J. Aqua. Biol. Fisheries, $\quad \mathbf{2 3}(1)$ : $\quad 245-252$. DOI: 10.21608/ejabf.2019.27278.

America Public Health Association (APHA). 1989. Standard Methods for Examination of Water and Wastewater (17th edition). Washington DC, USA.

Avkhimovich D. 2013. Effect of water quality on rainbow trout performance Water oxygen level in commercial trout farm "Kala jamarjapojat" (Bachelor's Thesis, Mikkeli University of Applied Sciences). https://www.theseus.fi/bitstream/handle/ 10024/57500/Avkhimovich\%20Dmitry.p df? sequence $=1.77 \mathrm{p}$.

Ayoade AA, Fagade SO, Adebisi AA. (2006). Dynamics of limnological features of two man-made lakes in relation to fish production. African J. Biotech., 5(10): 1013-1021.

Bhateria R, Jain D. 2016. Water quality assessment of lake water: a review. Sustainable Water Res. Management, 2(2): 161-173. DOI: https://doi.org/10.1007/s40899-0150014-7

Bhattacharya AK, Bolaji GA. 2010. Fluid flow interactions in Ogun River, Nigeria. Int. J. Res. Rev. App. Sci., 2(2): 173-178. 
Björnsson B, Ólafsdóttir SR. 2005. Effects of water quality and stocking density on growth performance of juvenile cod (Gadus morhua L.). ICES J. Marine Sci., 63(2): 326-334. DOI: https://doi.org/10.1016/j.icesjms.2005.10 .010

Bouillon S, Yambélé A, Gillikin DP, Teodoru C, Darchambeau F, Lambert T, Borges AV. 2014. Contrasting biogeochemical characteristics of the Oubangui River and tributaries (Congo River basin). Sci Rep., 4: 5402. DOI: 10.1038/srep05402.

Boulton CE. 2012. Assessment of Elemental and Microbial Quality of Lake Efi in Bayelsa State, Central Niger Delta, Nigeria. J. Environ. Treatment Tech., 3(3): 71 - 75.

Crane B. 2006. Results of Water quality Measurements in Messer Pond. http://www.messerpond.org/Ecolo gy/WaterSamplingSummary.pdf.

Eniade AA, Bello-Olusoji AO. 2011. The abiotic ecology of breeding ground of palaemonid prawns in the Ilaje estuary, Ondo State, Nigeria. Continental $J$. Fisheries Aqua. Sci., 5(1): 31 - 37.

Federal Office for the Environment (FOEN), 2011, Indicator Water temperature of surface waters, Department of the Environment, Transport, Energy and Communications, www.bafu.admin.ch.

Ikomi RB, Sikoki FD. 2003. Studies on the Biology of the African lonfin Tetra, Brycinus longipinnis (Gunther, 1964) in the Jamieson River (Niger Delta, Nigeria) Acta Ichthyologia et Piscatoria, 33(I): 17-36.

Issa EA, Olufeagba SO, Raji A. 2005. Effects of some environmental factors on the fecundity of Tilapia species (Family Cichlidae) in Kigera Reservoir, New Bussa. In: 19th Annual Conference of the Fisheries Society of Nigeria (FISON), 29 Nov - 03 Dec 2004, Ilorin, Nigeria, 861-868.

Kamal D, Khan AN, Rahman MA, Ahamed F. 2007. Study on the Physico Chemical Properties of Water of Mouri River, Khulna, Bangladesh. Pakistan J. Bio.
Sci.,

10:

710-717.

DOI: $10.3923 /$ pjbs.2007.710.717

Kausar R, Salim M. 2006. Effect of water temperature on the growth performance and feed conversion ratio of Labeo rohita. Pakistan Vet. J., 26(3): 105-108.

Makori AJ, Abuom PO, Kapiyo R, Anyona DN, Dida GO. 2017. Effects of water physico-chemical parameters on tilapia (Oreochromis niloticus) growth in earthen ponds in Teso North SubCounty, Busia County. Fisheries Aqua. Sci., 20: 30-40.

Mallya YJ. 2007. The effects of dissolved oxygen on fish growth in aquaculture. The United Nations University Fisheries Training Programme, Reykjavik, Iceland.

Mohammed B, Tewabe D, Zelalem W,Melaku A. 2016. Physical, Chemical, Biological properties and fish species type of Geray reservoir, -W/Gojjam Zone, Ethiopia. Int. J. Aqua. Fisheries Sci., 2(1): 008011. DOI: $10.17352 / 2455-8400.000012$.

Moiseenko TI. 2010. Effect of toxic pollution on fish populations and mechanisms for maintaining population size. Russ. J. Ecol., 41: 237-243. https://doi.org/10.1134/S106741361003 007

Munoz H, Orozco S, Vera A, Jiménez J. 2015. Relationship between Dissolved Oxygen, Rainfall and Temperature: Zahuapan River, Tlaxcala, Mexico. Tecnologia $Y$ Ciencias Del Agua, 6(5):59-74.

Oketola AA, Osibanjo O, Ejelonu BC, Oladimeji YB, Damazio OA. 2006. Water Quality Assessment of River Ogun around the Cattle Market of Isheri, Nigeria. J. App. Sci., 6(3): 511-517.

Olalekan EI, Kies F, Lawal-Are AO, Salau DR, Fashina-Bombata H, Akintola SL, Aderolu AZ, Ndimele E, Onyema IC, Fadeyi O. 2015 Effect of Water Quality Characteristics on Fish Population of the Lake Volta, Ghana. $J$. Environ. Anal. Toxicol., 5: 317-321. DOI:10.4172/2161-0525.1000317.

Olanrewaju AN, Ajani EK, Kareem OK, Orisasona

O.

2017. 
Relationship BetweenPhysico-Chemical Parameters and Reproductive Indices of Parachanna obscura (Gunther 1861) in Eleyele Reservoir, Ibadan, Nigeria. European J. Exp. Bio., 7(6): 36-41.

Olapade JO, Tarawallie S. 2014. The lengthweight relationship, condition factor and reproductive biology of Pseudotolithus senegalensis (Valenciennes, 1833) (croakers), in Tombo western rural district of Sierra Leone. African J. Food, Agric. Nutri. Dev., 14(6): 2176-2189.

Paugy, D. and S.A. Schaeferzz, 2007. Alestidae. In M.L.J. Stiassny, G.G. Teugels and C.D. Hopkins (eds.) Poissons d'eaux douces et saumâtres de basse Guinée, ouest de l'Afrique centrale/The fresh and brackish water fishes of Lower Guinea, west-central Africa. Vol. 1, 347-411.

Sagar TP, Singh S, Singh V, Baghel SR, Dwivedi AK. 2012. Effect of water $\mathrm{pH}$ on growth and production of fish in the Coka Dam PaparaDistt. Satna (M.P.). Int. J. Pharm. Life Sci., 3(9): 1979-1981.

Saliu JK. 2002. Size sex and seasonal dynamics in the dietary composition of Brycinus nurse (Pisces: Characidae), from Asa reservoir, Ilorin, Nigeria. Rev. Bio. Tropics.50: 233-238.

Suja B, Phillips H, Lochmann R, Chen R. 2009. Effect of Temperature on growth, feed utilization, and immune status of channel catfish in a recirculating system. North American Journal of Aquaculture, 71(1): 6472. DOI: 10.1577/A07-101.1.
Ufodike EBC, Kwanasie AS, Chude LA. 2001. On-set of rain and its destabilizing effect on aquatic physic-chemical parameters. J. Aqua. Sci., 16(2): 91-94.

Wang T, Jackson DC. 2016. How and why pH changes with body temperature: the $\alpha$ stat hypothesis. J. Exp. Bio., 219: 10901092. DOI: $10.1242 /$ jeb. 139220

Welcomme RL. 1985. River fisheries. Food and Agricultural Organization Fisheries Technical Paper, (262), FAO, Rome. 330 .

http://www.fao.org/docrep/003/T0537E/ T0537E00.HTM

Wetzel RG. 2001. Limnology: Lakes and River Ecosystems (3rd edn). Academic Press: New York; 1006p.

Willoughby W, Tweddle D. 1978. The ecology of the catfish, Clarias gariepinus and Clarias ngamensis in the Shire Valley, Malawi. J. Zoo., 186(4): 507-534.

Zhong J, Li SL, Tao F, FujunYue F, Liu CQ. Sensitivity of chemical weathering and dissolved carbon dynamics to hydrological conditions in a typical Karst River. Sci Rep., 7: 42944-42953. DOI: 10.1038/srep42944. 